\title{
Paradermal studies on the stomata of some species of Asteraceae
}

\author{
Harpreet Kaur and Avinash Kaur Nagpal ${ }^{\bowtie}$ \\ Department of Botanical and Environmental Sciences, Guru Nanak Dev University, Amritsar - 143005, Punjab, India \\ 凶Corresponding author: avnagpal@yahoo.co.in

\section{ऐस्टरेसी की कुछ जातियों के वातरंध्र पर आधारित (पैराडर्मल) \\ अध्ययन}

\author{
हरप्रीत कौर, अविनाश कौर नागपाल
}

\section{सारांश}

वातरंध्र (स्टोमैटा) एक विशेष प्रकार की संरचनायें हैं, जो पौधे और पर्यावरण के मध्य गैसों के (कार्बनडाइक्साइड और ऑक्सिजन) आदान प्रदान का कार्य कर दो महत्वूर्ण शारीरिकीय कार्यों -प्रकाश संश्लेषण एवं श्वसन का निर्वहन करती हैं। वातंर्धों की संरचना पादप वर्गिकी में पौधे की पहचान के अभिनिर्धारण में भी महत्वपूर्ण है। प्रस्तुत शोध पत्र हल्क् सूक्ष्कदर्शी और स्कैनिंग इलैक्ट्रॉन माइक्रोस्कोप का उपयोग कर ऐस्टरेसी कुल की 15 जातियों के वातरंध्र पर के अंत:सतही (पैराडर्मल) अध्ययन से सम्बन्धित है। अध्ययन से ज्ञात होता है कि वातर्ध संरचना एवं पत्ते के ऊपरी (एडेक्सयल) एवं निचली सतहों (एबेक्सियल) पर पाये जाने स्टोमैटा की संख्या में भिन्नता है । इस अध्ययन से दो प्रकार के स्टोमैटा जैसे एनोमोसाइटिक (अनियमित कोशिका) एवं एनियोसाइटिक (असमान कोशिका) अवलोकित किये गये हैं। ऐस्टरेसी कुल की विभिन्न जातियों के पत्तों पर किये गये अध्ययन से पता चलता है कि इनके वातरंध्र का घनत्व निचली सतह पर 41.519 मि.मि. $^{-2}$ (गिलार्डिया पुलचेल्ला) से $276.166^{-2}$ मि.मि. (हेलेंथस एन्नूसो) के रेंज में एवं ऊपरी सतह पर 23.90 मि. मि. $^{-2}$ (गिलारडिया पुलचेल्ला) से 225.83 मि.मी. ${ }^{-2}$ (वेलडिलिया ट्राइलोबाटा) तक है। 13 जातियो के स्टोमैटा मध्यम आकार के हैं और दो जातियों गिलार्डिया पुलचेल्ला एवं जिनिया मल्टिफेरा के स्टोमैटा बृहताकार के हैं.

\section{ABSTRACT}

Stomata are specialized structures responsible for exchange of gases i.e. $\mathrm{CO}_{2}$ and $\mathrm{O}_{2}$ between plants and the environment thereby performs two important physiological functions, viz., photosynthesis and respiration. The structure of stomata is considered as important taxonomic tool for identification of plants. The present paper deals with the paradermal studies on the stomata of 15 species of family Asteracece done through light microscope and scanning electron microscope. The study reveals a considerable difference in the structures and number of stomata found on the adaxial and abaxial surfaces of the leaf. Two types of stomatal types viz. anomocytic (irregular celled) and anisocytic (unequal celled) were observed in the present study. Stomatal density was found to be ranging from $41.519 \mathrm{~mm}^{-2}$ (Gillardia pulchella) to $276.166 \mathrm{~mm}^{-2}$ (Helianthus annuus) on the abaxial surface of leaves while $23.90 \mathrm{~mm}^{-2}$ (Gillardia pulchella) to $225.83 \mathrm{~mm}-2$ (Wedelia trilobata) on the adaxial surface of leaves of selected species of Asteraceae. Stomata of 13 species were of medium size and only two species Gillardia pulchella and Zinnia multiflora showed stomata to be of large size.

Keywords: Paradermal Study, Taxonomy, Asteraceae, Stomata, Stomatal density 


\section{INTRODUCTION}

The taxonomic relevance of foliar epidermal structures like stomata and trichomes has been well documented (Adedeji and Illoh, 2004; Adedeji, 2004; Celka \& al., 2006; Dehgan, 1980; Jayeola and Adenegan, 2001; Parveen \& al., 2000; Yasmin \& al., 2009; Zou \& al., 2008). The term stoma (plural stomata), is derived from Greek, which means 'opening or mouth' and includes both the guard cells and the pore between them. Stomata are concerned with exchange of gases $\left(\mathrm{CO}_{2}\right.$ and $\mathrm{O}_{2}$ between plants and the environment), which is important for two most important life processes- photosynthesis and respiration. They also play a crucial role in transpiration due to their involvement in loss of excess water absorbed from the soil. Since photosynthesis is considered as a major factor for determining crop yield, the study of stomata becomes important for studies related to factors affecting crop yield (Rahman, 2011).

The family Asteraceae is represented by more than 30,000 and over 1100 genera. In India, the family is represented by 167 genera and ca 900 species (http://efloraindia.nic.in/). Majority of the species are herbaceous, but other forms like shrubs, succulents, lianas, epiphytes and rarely trees are also found (Bremer, 1994; Dutta, 1974; Funk \& al., 2005; Mbagwu \& al., 2006).

Many plants of the family are economically important, and are also used as ornamentals (Aster amellus, Chrysanthemum indicum, Cosmos bipinnatus, Dahlia pinnata, Helianthus annuus, Tagetes erecta, Zinnia americana etc.), in medicines (Mikania glomerata, Porophyllum ruderale and Vernonia condensata etc.) or vegetables (Crassocephalum crepidioides, Helianthus annuus, Lactuca sativa (lettuce), Launaea taraxacifolia, Vernonia amygdalina (bitter leaf) while others are weeds (Chromolaena odorata, Tridax procumbens, Ageratum conyzoides). Since Asteraceae is the largest family of flowering plants and structure of stomata is considered as an important aid in identification of plants, the present paper involves Light Microscopic and Scanning Electron Microscopic studies on the stomata of 15 species of Asteraceae collected from Amritsar, Punjab, India.

\section{MATERIALS AND METHODS}

The different area of Amritsar was surveyed and young leaves of 15 plant species of the family Asteraceae were collected. These areas were chosen as they represent most of the plant diversity of Amritsar. Table 1 gives the tribe wise list of plant species covered in the present study. The herbarium specimens of these plant species were prepared and submitted to the herbarium of Department of Botanical and Environmental Sciences, Guru Nanak Dev University, Amritsar (GNDUH) and Botanical Survey of India, Northern Regional Centre, Dehra Dun (BSD) (www.bsi.gov.in). Leaves were fixed in Formalin- Acetic acid- Alcohol (FAA) for $24 \mathrm{hrs}$ and subsequently stored in 70\% alcohol. The epidermal peelings from both the adaxial and abaxial surfaces were separately stripped off smoothly either with the help of needles and forceps from the middle portion of the leaf or by impression technique (Hilu \& Randall, 1984). The epidermal peelings were stained in $1 \%$ aqueous Safranin and mounted in Glycerine for microscopic study. For impression technique, a thin layer of transparent nail polish was directly applied to the surface of leaf. After drying, the impression left on the polish layer produced detailed image of the epidermis. The prepared slides were studied under light microscope (Olympus microscope MLXi Freedom Microscope) fitted with Olympus SLR digital camera. The ocular micrometer calibrated with the stage micrometer was used to study different parameters. The parameters studied were the type and frequency of stomatal complex on each epidermis, density (number of stomata per square millimeter), stomatal index (number of stomata per square millimeter/ number of stomata + number of epidermal cells per square millimeter X 100 (Dilcher, 1974), size of stomata (length/width of stomata ( stomatal pore + guard cells) average of 10 readings and length of stomatal pore (average of 10 readings). The statistical evaluation of the stomata included mean and standard error. For scanning electron microscopy, a piece of dried leaf was mounted on a metallic stub with the help of double adhesive tape and coated with silver and examined under SEM (Carl Zeiss EVO LS-10). Terminologies of the stomatal complex types used in this study are those of Dilcher (1974) and Metcalfe and Chalk (1950).

\section{RESULT AND DISCUSSION}

Stomatal characteristics such as type of stomatal complex, stomatal density and stomatal index of 15 species of Asteraceae are given in Table 2. Stomata are lens shaped present on both surfaces of the leaves 
Table 1: Details of plant species collected.

\begin{tabular}{|c|c|c|c|c|c|}
\hline Tribe & Sub Tribe & Plant Name & Collection site & $\begin{array}{l}\text { Date of } \\
\text { collection }\end{array}$ & Voucher No. \\
\hline Astereae & & Erigeron bonariensis L. & Namak Mandi, Amritsar & $23 / 03 / 2012$ & $\begin{array}{l}\text { GNDUH 6915, GNDUH } \\
6916 \text {, GNDUH 6917, } \\
\text { BSD } 115236\end{array}$ \\
\hline \multirow[t]{3}{*}{ Cichorieae } & Lactuceae & Launaea residifolia $\mathrm{L}$. & Mall road, Amritsar & $03 / 05 / 2012$ & $\begin{array}{l}\text { GNDUH 6849, GNDUH } \\
6850, \text { BSD } 115226\end{array}$ \\
\hline & & Sonchus oleraceus L. & Maquboolpura road, Amritsar & $05 / 03 / 2012$ & $\begin{array}{l}\text { GNDUH 6909, GNDUH } \\
6910\end{array}$ \\
\hline & & Sonchus wightianus DC. & $\begin{array}{l}\text { Khalsa College of Veterinary and } \\
\text { Animal Sciences }\end{array}$ & $20 / 09 / 2013$ & GNDUH 6995 \\
\hline \multirow[t]{8}{*}{ Heliantheae } & & Cosmos bipinnatus Cav. & $\begin{array}{l}\text { Botanical Garden, GNDU, } \\
\text { Amritsar }\end{array}$ & $12 / 04 / 2013$ & $\begin{array}{l}\text { GNDUH 6930, GNDUH } \\
6931, \text { GNDUH 6932, } \\
\text { BSD } 115238\end{array}$ \\
\hline & & Eclipta alba (L.) Hassk. & $\begin{array}{l}\text { Botanical Garden, GNDU, } \\
\text { Amritsar }\end{array}$ & $02 / 08 / 2011$ & $\begin{array}{l}\text { GNDUH 6883, GNDUH } \\
6884, \text { GNDUH } 6885, \\
\text { GNDUH 6886, GNDUH } \\
6887, \text { BSD } 115231\end{array}$ \\
\hline & & Gillardia pulchella L. & Goll Bagh, Amritsar & $14 / 07 / 2012$ & $\begin{array}{l}\text { GNDUH 6836, GNDUH } \\
6837, \text { BSD } 115225\end{array}$ \\
\hline & & Helianthus annuus L. & Guru Nanak Stadium, Amritsar & $04 / 06 / 2013$ & $\begin{array}{l}\text { GNDUH 6935, GNDUH } \\
6936, \text { GNDUH 6937, } \\
\text { GNDUH 6938, GNDUH } \\
\text { 6939, GNDUH } \\
\text { 6940, GNDUH 6941, } \\
\text { BSD115239 }\end{array}$ \\
\hline & & Parthenium hysterophorus L. & Namak Mandi, Amritsar & $08 / 06 / 2011$ & $\begin{array}{l}\text { GNDUH 6877, GNDUH } \\
6878, \text { GNDUH 6879, } \\
\text { BSD } 115263\end{array}$ \\
\hline & & $\begin{array}{l}\text { Verbescinia enceliodes (Cav.) } \\
\text { Benth. \& Hooker f. ex Gray }\end{array}$ & Goll Bagh, Amritsar & $14 / 072012$ & GNDUH 6975 \\
\hline & & $\begin{array}{l}\text { Wedelia trilobata (L.) A.S. } \\
\text { Hitchc. }\end{array}$ & Company Bagh, Amritsar & $10 / 08 / 2013$ & GNDUH 6988 \\
\hline & & Zinnia multiflora L. & Guru Nanak Stadium, Amritsar & $04 / 06 / 2013$ & $\begin{array}{l}\text { GNDUH 6933, GNDUH } \\
6934, \text { BSD } 115246\end{array}$ \\
\hline \multirow[t]{2}{*}{ Inuleae } & Gnaphaleae & Gnaphalium purpureum L. & Circular Road, Amritsar & $09 / 11 / 2011$ & $\begin{array}{l}\text { GNDUH 6891, GNDUH } \\
6892, \text { GNDUH 6893, } \\
\text { GNDUH 6894, BSD } \\
115233\end{array}$ \\
\hline & Plucheineae & Blumea mollis D. Don. & Kotatma ram, Amritsar & $26 / 02 / 2013$ & $\begin{array}{l}\text { GNDUH 6925, GNDUH } \\
6926 \text {, GNDUH 6927, } \\
\text { BSD } 115237\end{array}$ \\
\hline Tageteae & & Tagetes erecta L. & Guru Nanak Stadium, Amritsar & $04 / 06 / 2013$ & $\begin{array}{l}\text { GNDUH 6981, GNDUH } \\
6982\end{array}$ \\
\hline
\end{tabular}


Table 2: Stomatal characteristics in studied species of Asteraceae

\begin{tabular}{|c|c|c|c|c|c|c|c|}
\hline \multirow[t]{2}{*}{ Tribe } & \multirow[t]{2}{*}{ Sub Tribe } & \multirow[t]{2}{*}{ Plant Name } & \multirow{2}{*}{$\begin{array}{l}\text { Leaf } \\
\text { Surface }\end{array}$} & \multicolumn{2}{|c|}{ Stomatal complex } & \multirow{2}{*}{$\begin{array}{l}\text { Stomatal } \\
\text { density } \\
\left(\mathrm{mm}^{-2}\right)\end{array}$} & \multirow{2}{*}{$\begin{array}{l}\text { Stomatal } \\
\text { index (SI) }\end{array}$} \\
\hline & & & & Type & $\begin{array}{l}\text { Frequency } \\
(\%)\end{array}$ & & \\
\hline \multirow[t]{2}{*}{ Astereae } & & Erigeron bonariensis L. & Abaxial & Anomocytic & 100.00 & 165.44 & $20.34 \%$ \\
\hline & & & Adaxial & Anomocytic & 100.00 & 121.41 & $20.38 \%$ \\
\hline \multirow[t]{6}{*}{ Cichorieae } & Lactuceae & Launaea residifolia L. & Abaxial & $\begin{array}{l}\text { Anomocytic } \\
\text { Anisocytic }\end{array}$ & $\begin{array}{l}66.43 \\
33.57\end{array}$ & 262.32 & $30.82 \%$ \\
\hline & & & Adaxial & Anomocytic & 100.00 & 178.65 & $28.60 \%$ \\
\hline & & Sonchus oleraceus L. & Abaxial & Anomocytic & 100.00 & 130.21 & $35.20 \%$ \\
\hline & & & Adaxial & Anomocytic & 100.00 & 56.61 & $19.14 \%$ \\
\hline & & Sonchus wightianus DC. & Abaxial & $\begin{array}{l}\text { Anomocytic } \\
\text { Anisocytic }\end{array}$ & $\begin{array}{l}78.08 \\
21.91\end{array}$ & 137.76 & $10.49 \%$ \\
\hline & & & Adaxial & Anomocytic & 100.00 & 69.82 & $7.97 \%$ \\
\hline \multirow[t]{16}{*}{ Heliantheae } & & Cosmos bipinnatus Cav. & Abaxial & $\begin{array}{l}\text { Anomocytic } \\
\text { Anisocytic }\end{array}$ & $\begin{array}{l}61.72 \\
38.27\end{array}$ & 211.95 & $34 \%$ \\
\hline & & & Adaxial & Anomocytic & 100.00 & 104.42 & $19.85 \%$ \\
\hline & & Eclipta alba (L.) Hassk. & Abaxial & Anomocytic & 100.00 & 256.65 & $20.18 \%$ \\
\hline & & & Adaxial & Anisocytic & 100.00 & 188.8 & $20.12 \%$ \\
\hline & & Gillardia pulchella L. & Abaxial & Anomocytic & 100.00 & 41.519 & $17.88 \%$ \\
\hline & & & Adaxial & Anomocytic & 100.00 & 23.90 & $13.33 \%$ \\
\hline & & Helianthus annuus L. & Abaxial & Anomocytic & 100.00 & 276.166 & $33.16 \%$ \\
\hline & & & Adaxial & Anisocytic & 100.00 & 195.01 & $32.63 \%$ \\
\hline & & Parthenium hysterophorus L. & Abaxial & Anomocytic & 100.00 & 171.11 & $24.28 \%$ \\
\hline & & & Adaxial & Anisocytic & 100.00 & 139.65 & $23.36 \%$ \\
\hline & & Verbescinia enceliodes (Cav.) Bentham & Abaxial & Anomocytic & 100.00 & 110.71 & $26.07 \%$ \\
\hline & & \& Hooker fil. ex Gray & Adaxial & Anomocytic & 100.00 & 58.50 & $23.25 \%$ \\
\hline & & Wedelia trilobata (L.) A.S. Hitchc. & Abaxial & Anisocytic & 100.00 & 269.87 & $23.02 \%$ \\
\hline & & & Adaxial & Anomocytic & 100.00 & 225.83 & $20.71 \%$ \\
\hline & & Zinnia multiflora L. & Abaxial & $\begin{array}{l}\text { Anomocytic } \\
\text { Anisocytic }\end{array}$ & $\begin{array}{l}77.19 \\
22.81\end{array}$ & 116.37 & $22.28 \%$ \\
\hline & & & Adaxial & $\begin{array}{l}\text { Anomocytic } \\
\text { Anisocytic }\end{array}$ & $\begin{array}{l}83.33 \\
16.66\end{array}$ & 135.87 & $24.36 \%$ \\
\hline \multirow[t]{4}{*}{ Inuleae } & Gnaphaleae & Gnaphalium purpureum L. & Abaxial & $\begin{array}{l}\text { Anomocytic } \\
\text { Anisocytic }\end{array}$ & $\begin{array}{l}84.15 \\
15.84\end{array}$ & 127.07 & $34.94 \%$ \\
\hline & & & Adaxial & Anomocytic & 100.00 & 42.96 & $13.27 \%$ \\
\hline & Plucheineae & Blumea mollis D. Don. & Abaxial & Anomocytic & 100.00 & 114.49 & $24.86 \%$ \\
\hline & & & Adaxial & Anisocytic & 100.00 & 123.29 & $25 \%$ \\
\hline \multirow[t]{2}{*}{ Tageteae } & & Tagetes erecta L. & Abaxial & Anomocytic & 100.00 & 254.14 & $21.08 \%$ \\
\hline & & & Adaxial & Anomocytic & 100.00 & 171.73 & $20.00 \%$ \\
\hline
\end{tabular}


(amphistomatic), often more numerous on abaxial epidermis than on adaxial. Guard cells are kidney shaped. Plates I-XV, shows Light and Scanning Electron micrographs of stomata of different species studied. Literature survey on stomatal studies of family Asteraceae revealed that among 15 different species investigated in the present study, stomatal study of only 5 species namely Eclipta alba, Helianthus annuus, Perthenium hysterophorus, Wedelia trilobata and Launaea residifolia has been reported earlier (Perveen \& al., 2007; Mahbubur Rahman \& al., 2013; Mahbubur Rahman, 2013; Shaheen $\&$ al., 2012). Two types of stomatal complexes viz. Anomocytic and anisocytic were observed in the present study. According to classification of Metcalfe and Chalk (1950) and Dilcher (1974), Anisocytic stoma is a stoma completely surrounded by only three subsidiary cells variable in position, shape and size with one of the subsidiary cells distinctly small and Anomocytic stoma is stoma surrounded by four or more subsidiary cells, variable in position, shape and size.

The study reveals difference in type of stomata and number of stomata between adaxial and abaxial surfaces of the leaf and different species studied. Among the 15 species studied stomatal complexes of 5 species, namely Erigeron bonariensis L., Tagetes erecta L., Gillardia pulchella L., Verbesina enceliodes (Cav.) Bentham \& Hooker f. ex Gray and Launaea residifolia $\mathrm{L}$. were found to be only one type i.e., anomocytic in both abaxial and adaxial leaf surfaces whereas leaves of 10 other species (Table 2) showed both anomocytic and anisocytic stomatal complexes.
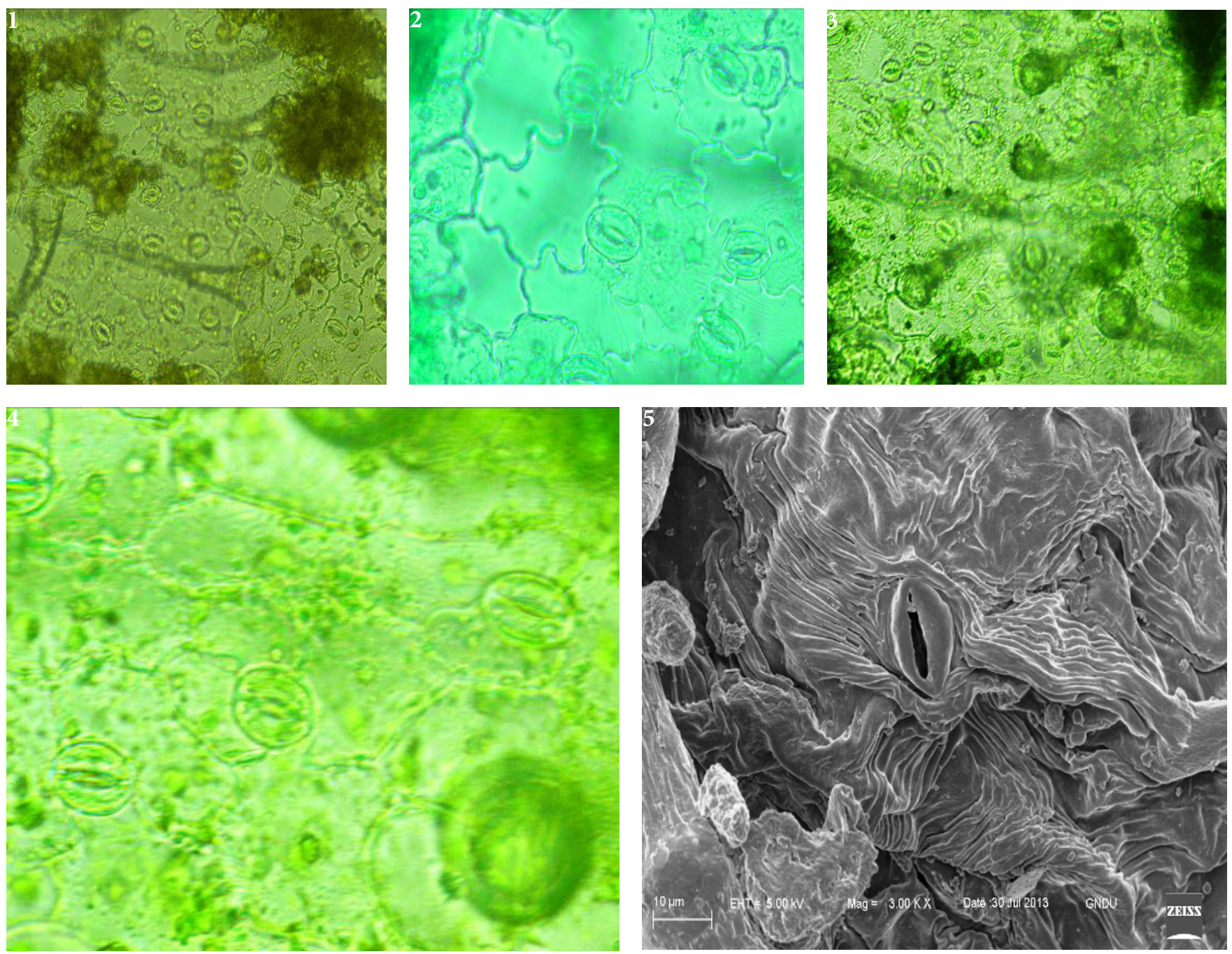

Plate -I. Light (1-4) and Scanning Electron Micrographs (5) of stomata of Erigeron bonariensis L.; 1, 2 - abaxial surface (40x, 100x); 3, 4 - adaxial surface (40x, 100x); 5 - abaxial surface (3.00 Kx, scale bar- 10 $\mu \mathrm{m})$. 

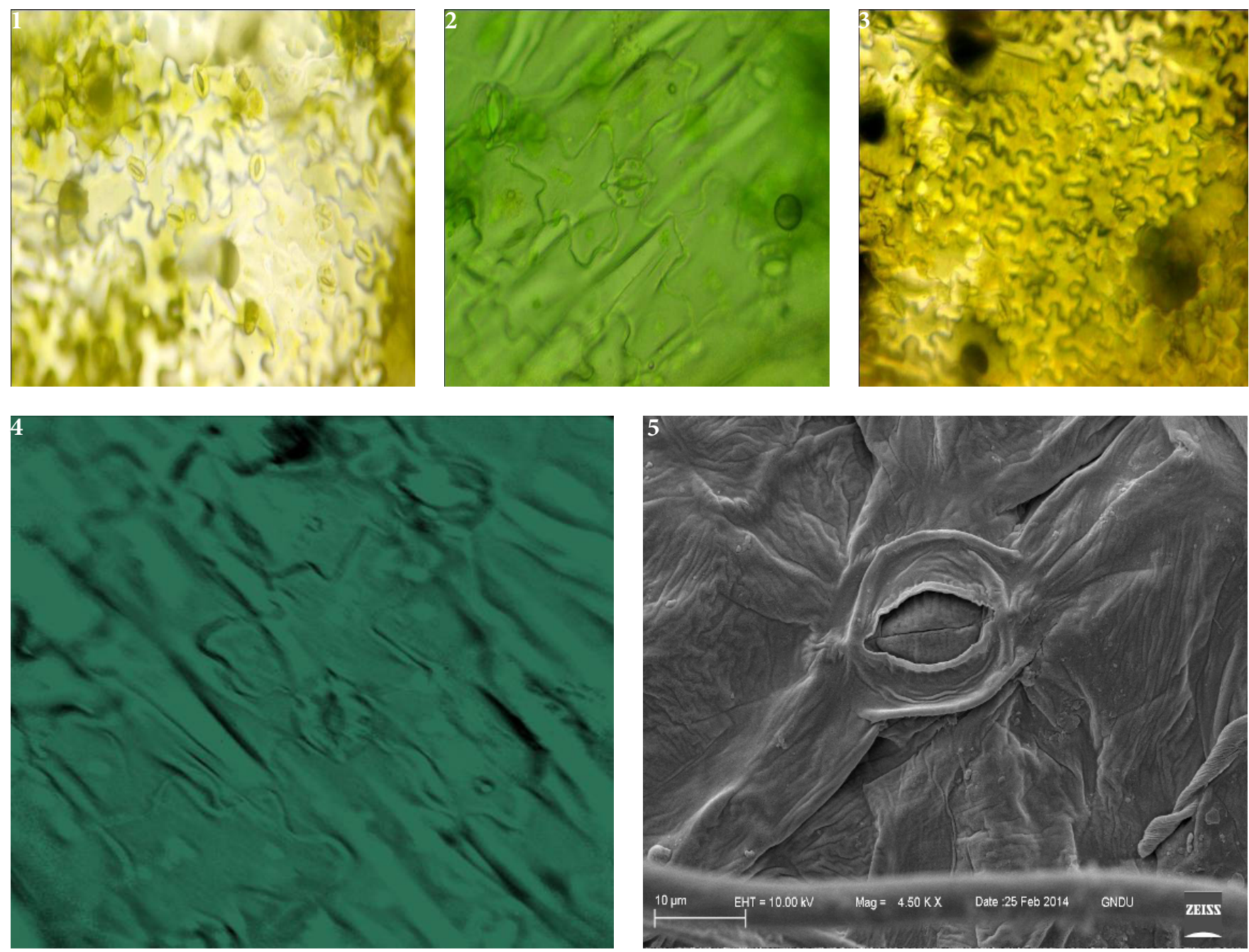

Plate -II. Light (1 - 4) and Scanning Electron Micrographs (5) of stomata of Gnaphalium purpureum L.; 1, 2- abaxial surface $(40 \mathrm{x}, 100 \mathrm{x}) ; 3,4$ - adaxial surface $(40 \mathrm{x}, 100 \mathrm{x}) ; 5$ - abaxial surface $(4.50 \mathrm{Kx}$, scale bar- $10 \mu \mathrm{m})$.

In Gnaphalium purpureum, Cosmos bipinnatus, Zinnia multiflora, Launaea residifolia, and Sonchus wightianus, the abaxial leaf surface was found to be possess both anomocytic and anisocytic stomatal complexes whereas frequency of anomocytic complexes was found to be more than that of anisocytic complexes. The adaxial leaf surfaces of these species were found to possess only anomocytic stomatal complexes except Zinnia multiflora where anisocytic stomata, though in low frequency, were also found on the adaxial surface.

In Eclipta alba, Helianthus annuus, Parthenium hysterophorus and Blumea mollis, abaxial leaf surfaces possessed only anomocytic stomatal complexes whereas adaxial surfaces displayed anisocytic complexes. Our results on type of stomatal complexes of Eclipta alba,
Helianthus annuus, Parthenium hysterophorus and Wedelia trilobata are in conformity with an earlier study by Mahbubur Rahman et al. (2013) who also reported two types of stomatal complexes (Anomocytic and Anisocytic) in these species.

Stomatal density range from $41.519 \mathrm{~mm}^{-2}$ (Gillardia pulchella to $276.166 \mathrm{~mm}^{-2}$ Helianthus annuus) on the abaxial surface of leaves and $23.90 \mathrm{~mm}^{-2}$ (Gillardia pulchella ) to $225.83 \mathrm{~mm}^{-2}$ (Wedelia trilobata) on adaxial surface of leaves of different species studied. Stomatal density was found to be more on the abaxial surface than on the adaxial surface in all species except Blumea mollis and Zinnia multiflora. Stomatal density has been used as one of the diagnostic features for distinguishing different species (Noggle and Fritz, 1976; Okeke, 2004). 

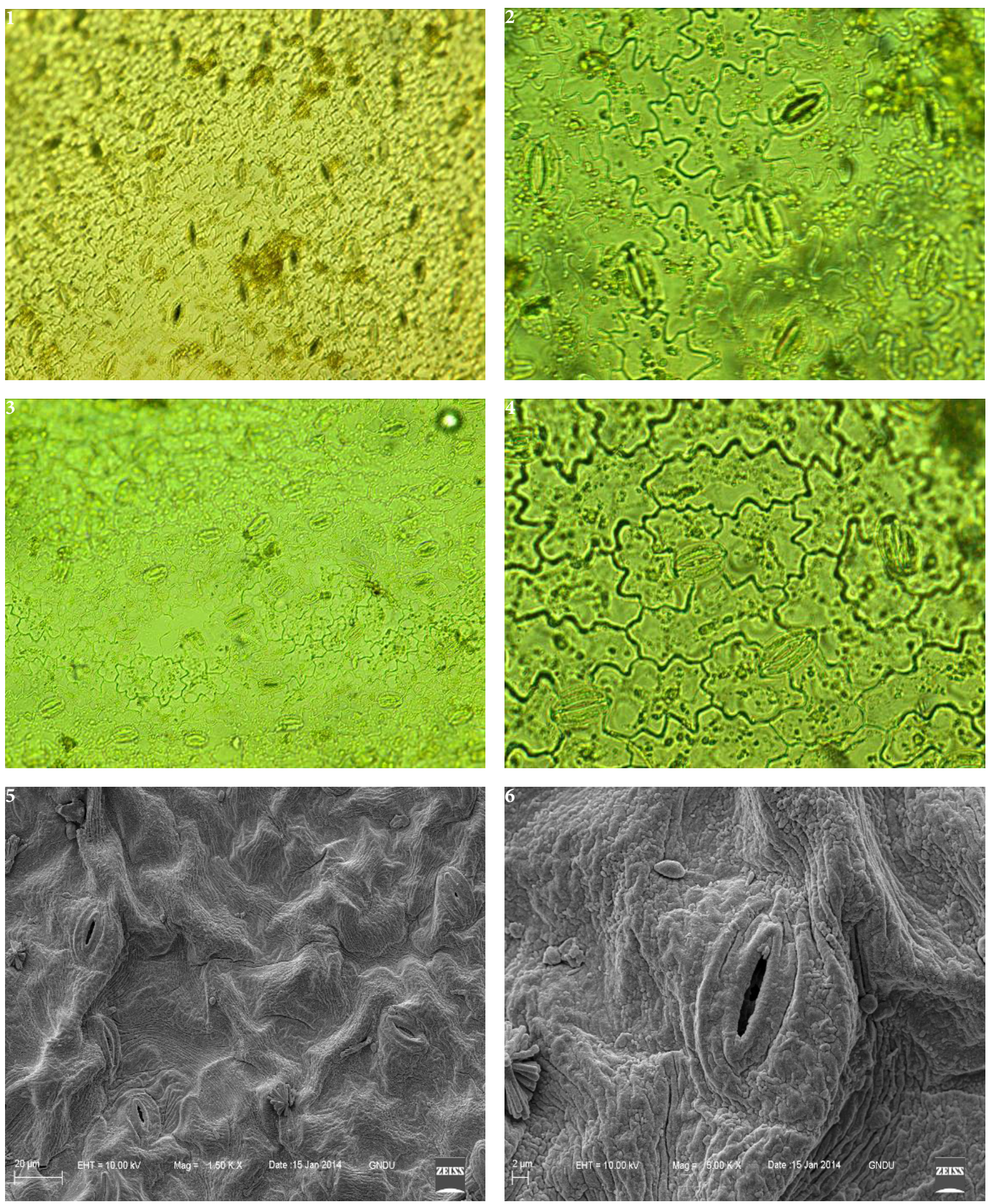

Plate -III. Light (1 - 4) and Scanning Electron Micrographs (5, 6) of stomata of Tagetes erecta L.; 1, 2- abaxial surface (40x, 100x); 3, 4 - adaxial surface (40x, 100x); 5, 6 - abaxial surface (1.50 Kx, $5.00 \mathrm{Kx}$, scale bar- $20 \mu \mathrm{m}, 2 \mu \mathrm{m})$. 

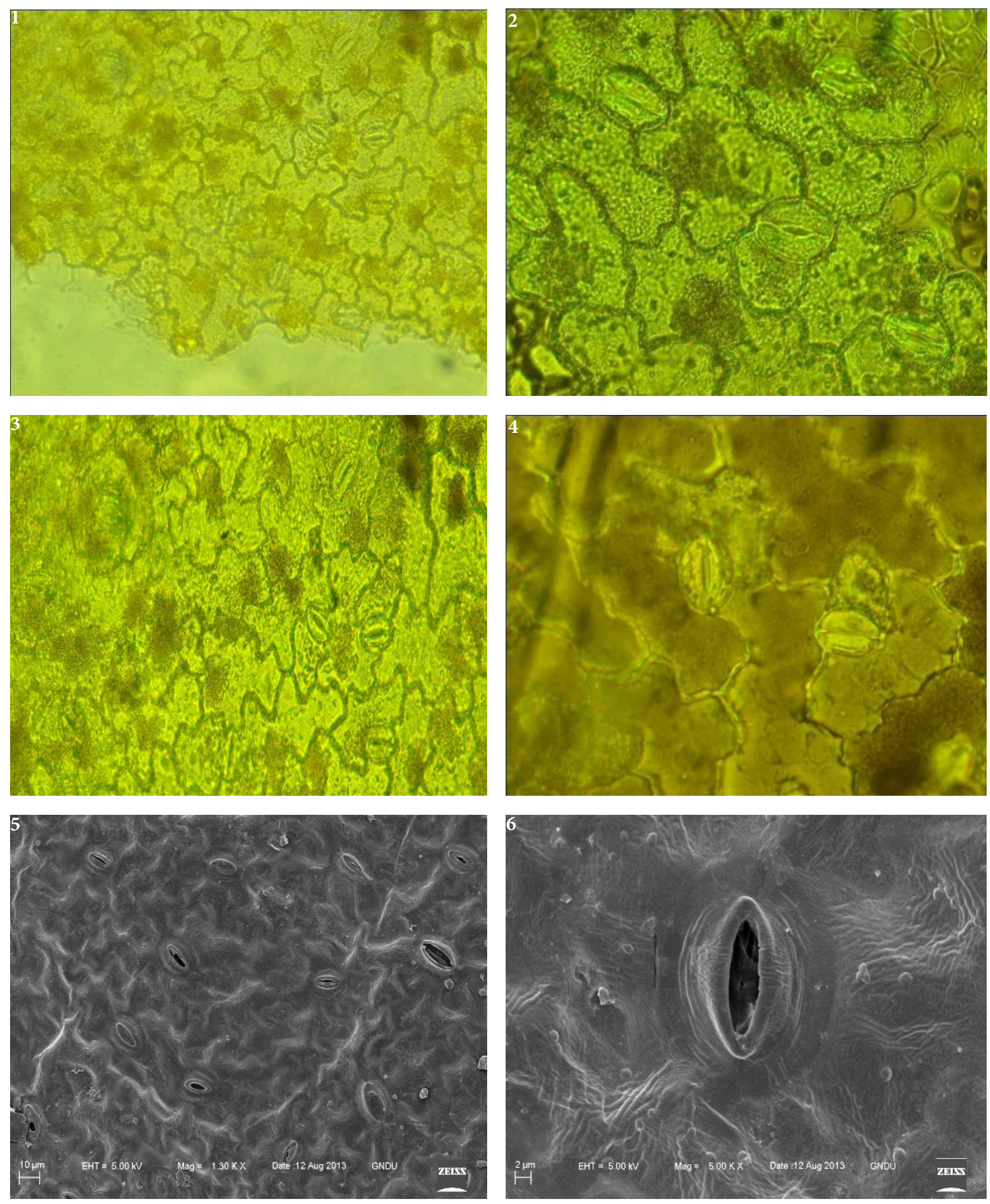

Plate -IV. Light (1 - 4) and Scanning Electron Micrographs $(5,6)$ of stomata of Cosmos bipinnatus Cav.; 1, 2- abaxial surface (40x, 100x); 3, 4 - adaxial surface (40x, 100x); 5, 6 - abaxial surface $(1.30 \mathrm{Kx}, 5.00 \mathrm{Kx}$, scale bar- $10 \mu \mathrm{m}, 2 \mu \mathrm{m})$. 

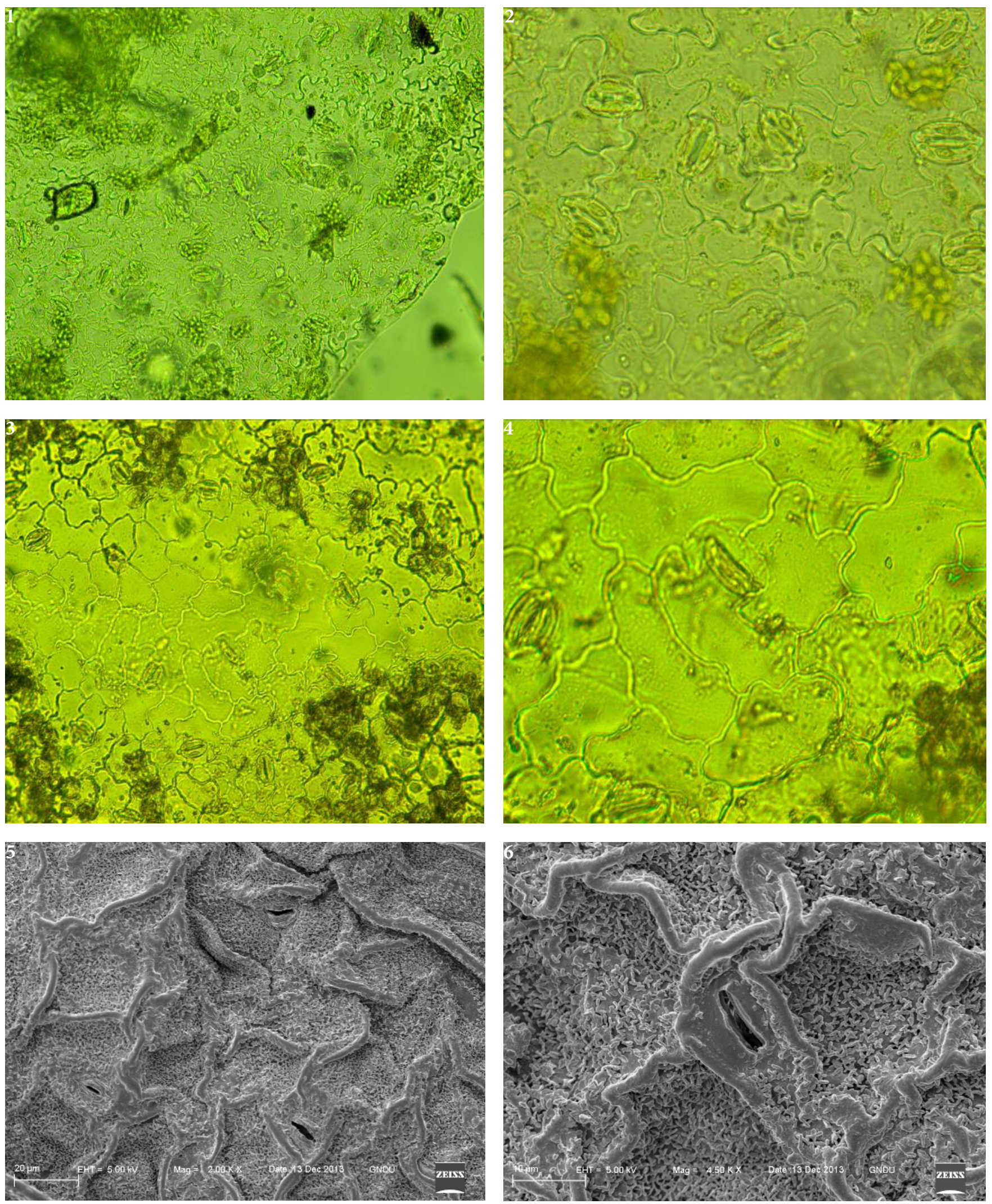

Plate -V. Light (1 - 4) and Scanning Electron Micrographs $(5,6)$ of stomata of Eclipta alba (L.) Hassk.; 1, 2- abaxial surface (40x, 100x); 3, 4 - adaxial surface (40x, 100x); 5, 6 - abaxial surface $(2.00 \mathrm{Kx}, 4.50 \mathrm{Kx}$, scale bar- $20 \mu \mathrm{m}, 10 \mu \mathrm{m})$. 

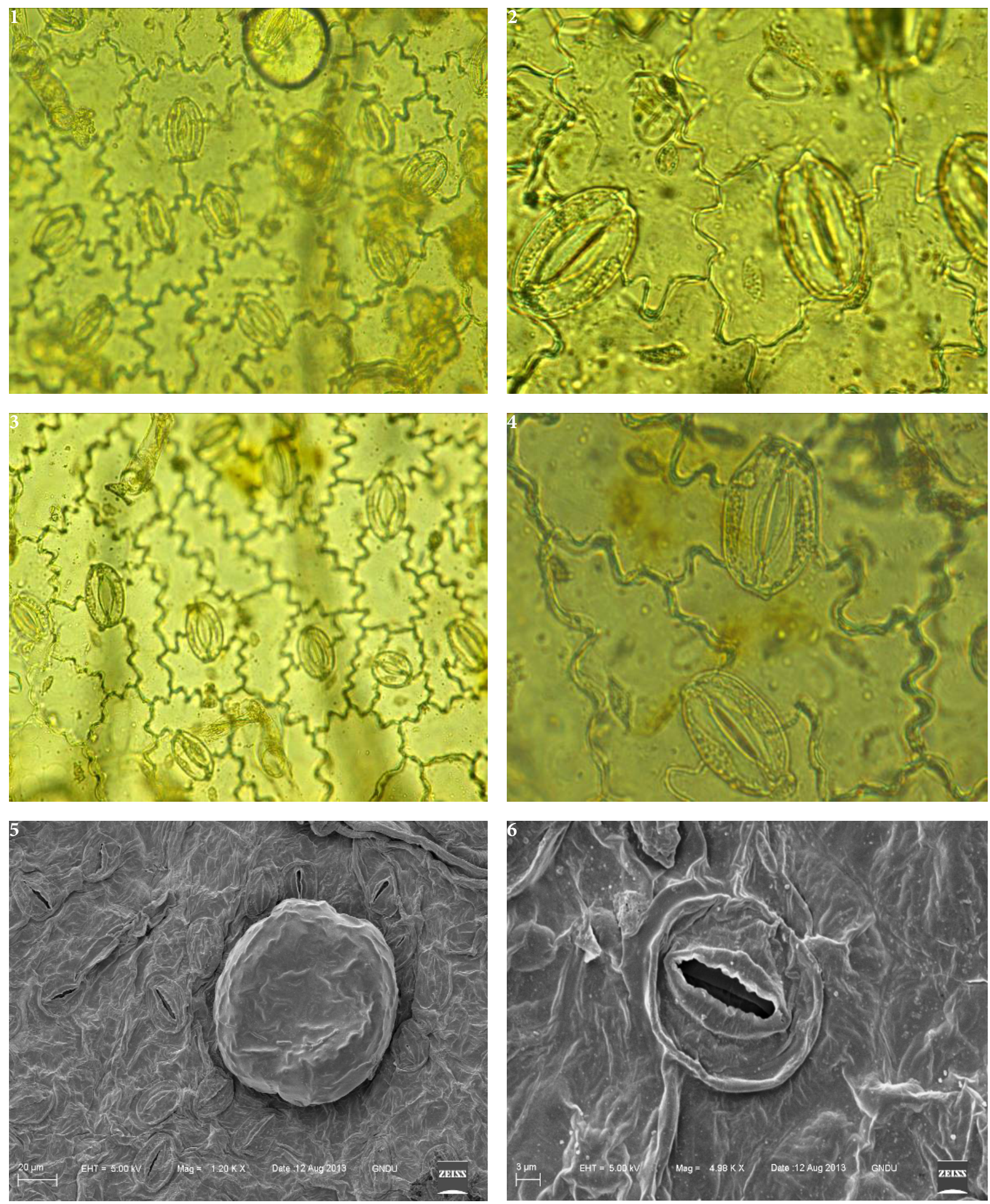

Plate -VI. Light (1 - 4) and Scanning Electron Micrographs $(5,6)$ of stomata of Gillardia pulchella L.; 1, 2- abaxial surface (40x, 100x); 3, 4 - adaxial surface (40x, 100x); 5, 6 - abaxial surface $(1.20 \mathrm{Kx}, 4.98 \mathrm{Kx}$, scale bar- $20 \mu \mathrm{m}, 3 \mu \mathrm{m})$. 

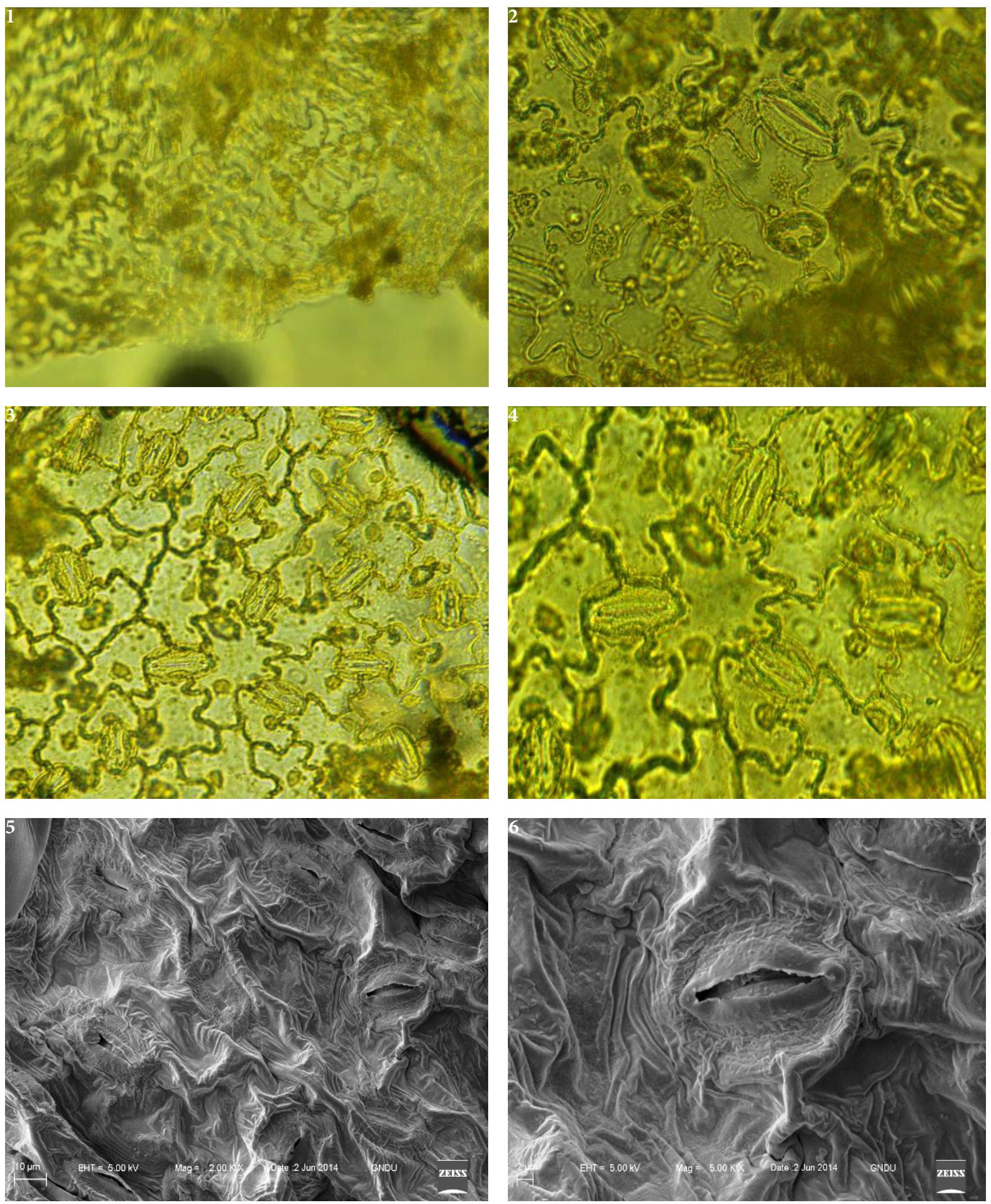

Plate -VII. Light (1 - 4) and Scanning Electron Micrographs $(5,6)$ of stomata of Helianthus annuus L.; 1, 2- abaxial surface (40x, 100x); 3, 4 - adaxial surface (40x, 100x); 5, 6 - abaxial surface $(1.20 \mathrm{Kx}, 4.98 \mathrm{Kx}$, scale bar- $20 \mu \mathrm{m}, 3 \mu \mathrm{m})$ 

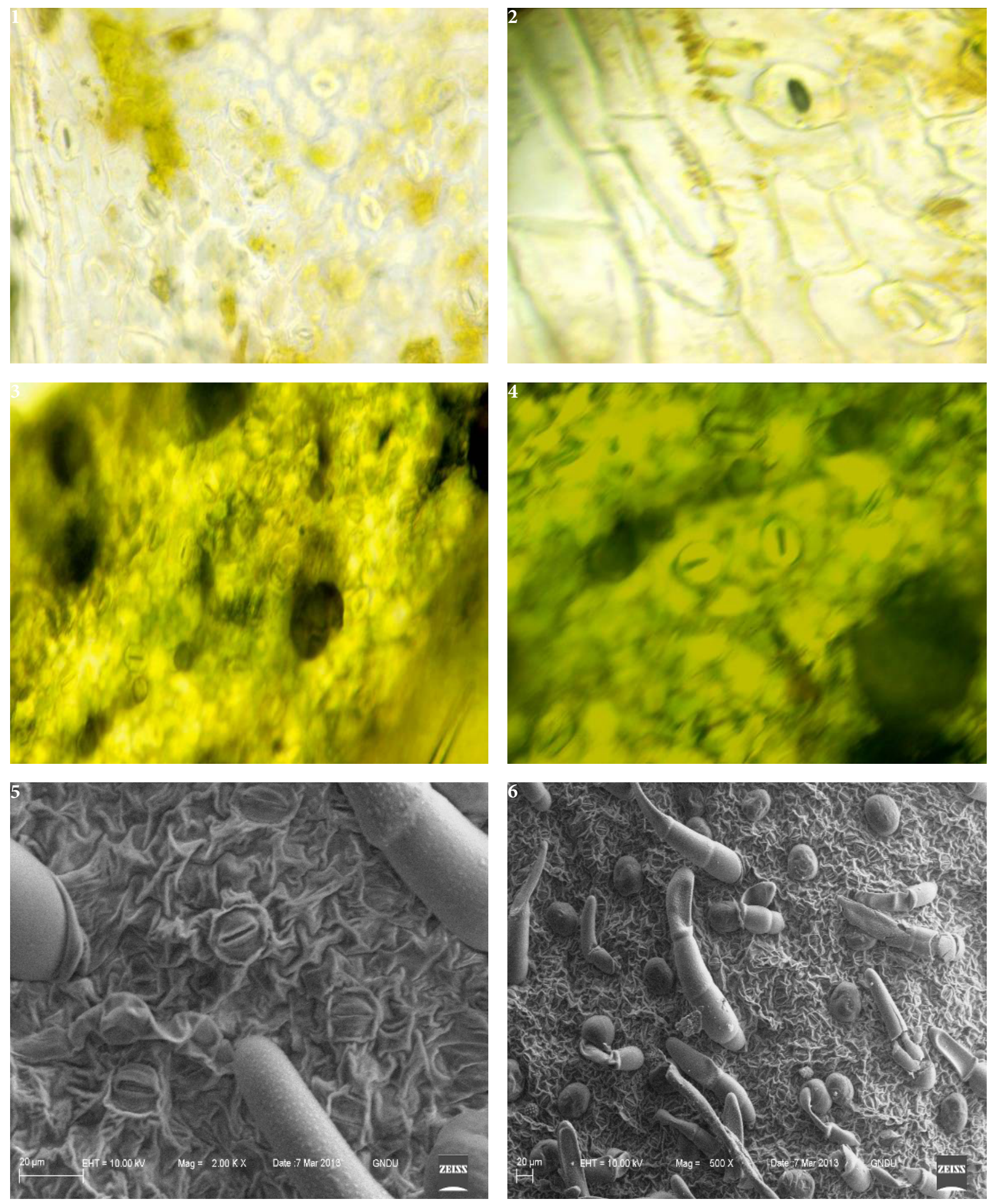

Plate -VIII. Light (1 - 4) and Scanning Electron Micrographs (5, 6) of stomata of Parthenium hysterophorus L.; 1, 2-abaxial surface (40x, 100x); 3, 4 - adaxial surface (40x, 100x); 5, 6 - abaxial surface $(2.00 \mathrm{Kx}, 500 \mathrm{x}$, scale bar- $20 \mu \mathrm{m}, 20 \mu \mathrm{m})$. 

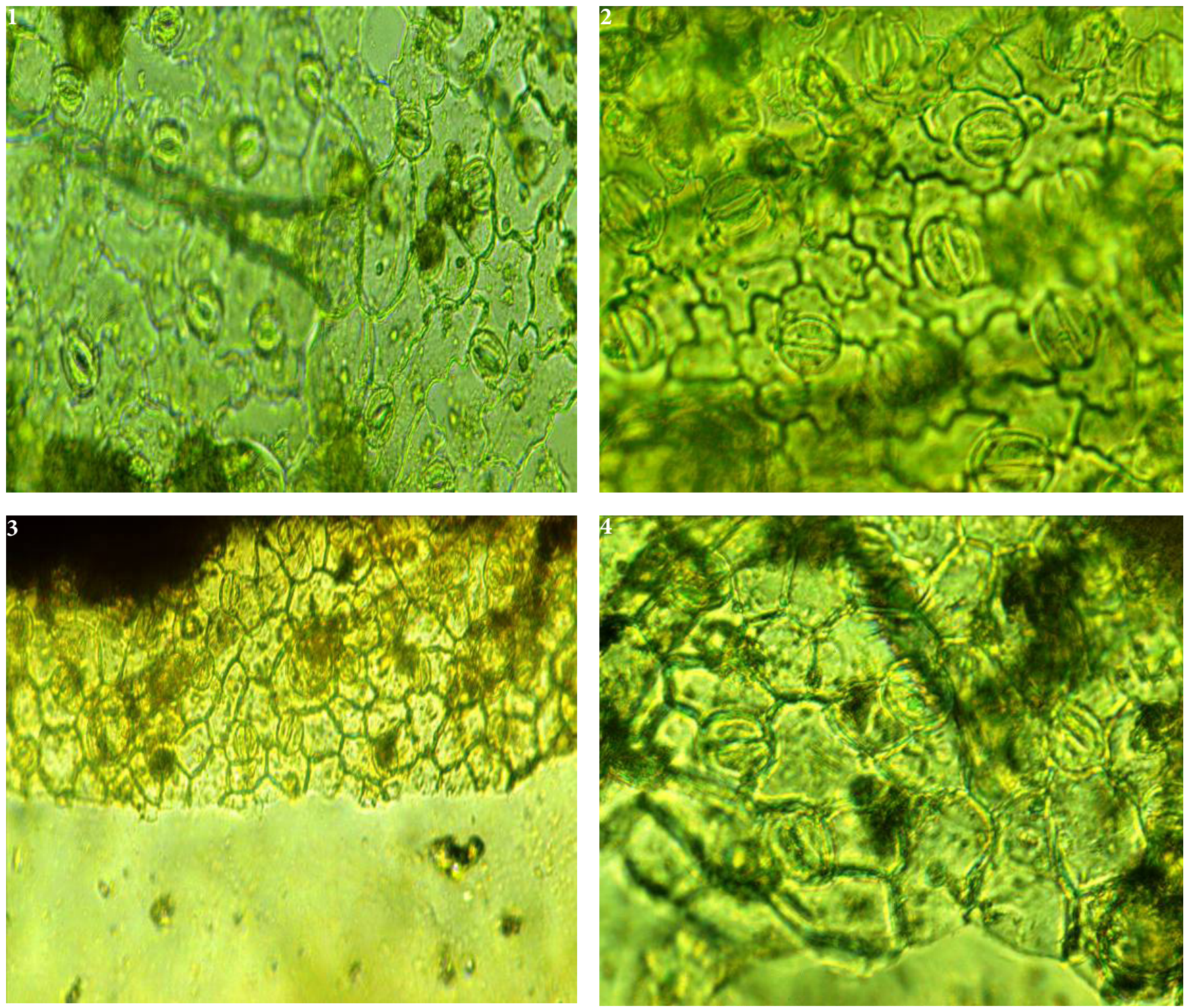

Plate -IX. Light (1 - 4) Micrographs of stomata of Verbescinia enceliodes (Cav.) Bentham \& Hooker fil. ex Gray.; 1, 2- abaxial surface $(40 \mathrm{x}, 100 \mathrm{x}) ; \mathbf{3 , 4}$ - adaxial surface $(40 \mathrm{x}, 100 \mathrm{x})$.

Stomatal index is considered as one of the reliable taxonomic characters because it is independent of the changes in size of epidermal cells brought about by environmental factors (Metcalfe and Chalk, 1988). On abaxial surfaces of leaves of different species studied, highest stomatal index was noticed in Sonchus oleraceae (35.20\%) and lowest in Sonchus wightianus (10.49\%) while on adaxial surfaces highest was found in of leaves Helianthus annuus (32.63\%) and lowest in Sonchus wightianus (7.97\%). Stomatal index can also aid in distinguishing species. It was found that stomatal index has low value on adaxial surface as compared to abaxial surface. High value of stomatal index is indicative of high transpiration rate, metabolism and high rate of absorption of minerals and water. Species with low stomatal index indicate that they grow in $\mathrm{CO}_{2}$ rich environment (mostly along road sides) and those with high value indicate they grow in environment with low air pollution or $\mathrm{CO}_{2}$ concentration (Munir \& al., 2011).

Table 3 gives the measurements of stomata of Asteraceae species studied. The stomatal size (stomatal pore + guard cells) ranged from $17.94 \times 15.33 \mu \mathrm{m}$ (Eclipta alba) to $52.72 \times 31.46 \mu \mathrm{m}$ (Zinnia multiflora) on abaxial surfaces of leaves and $20.84 \times 14.35 \mu \mathrm{m}$ (Tagetes erecta) to $53.54 \times 36.86 \mu \mathrm{m}$ (Zinnia multiflora) 

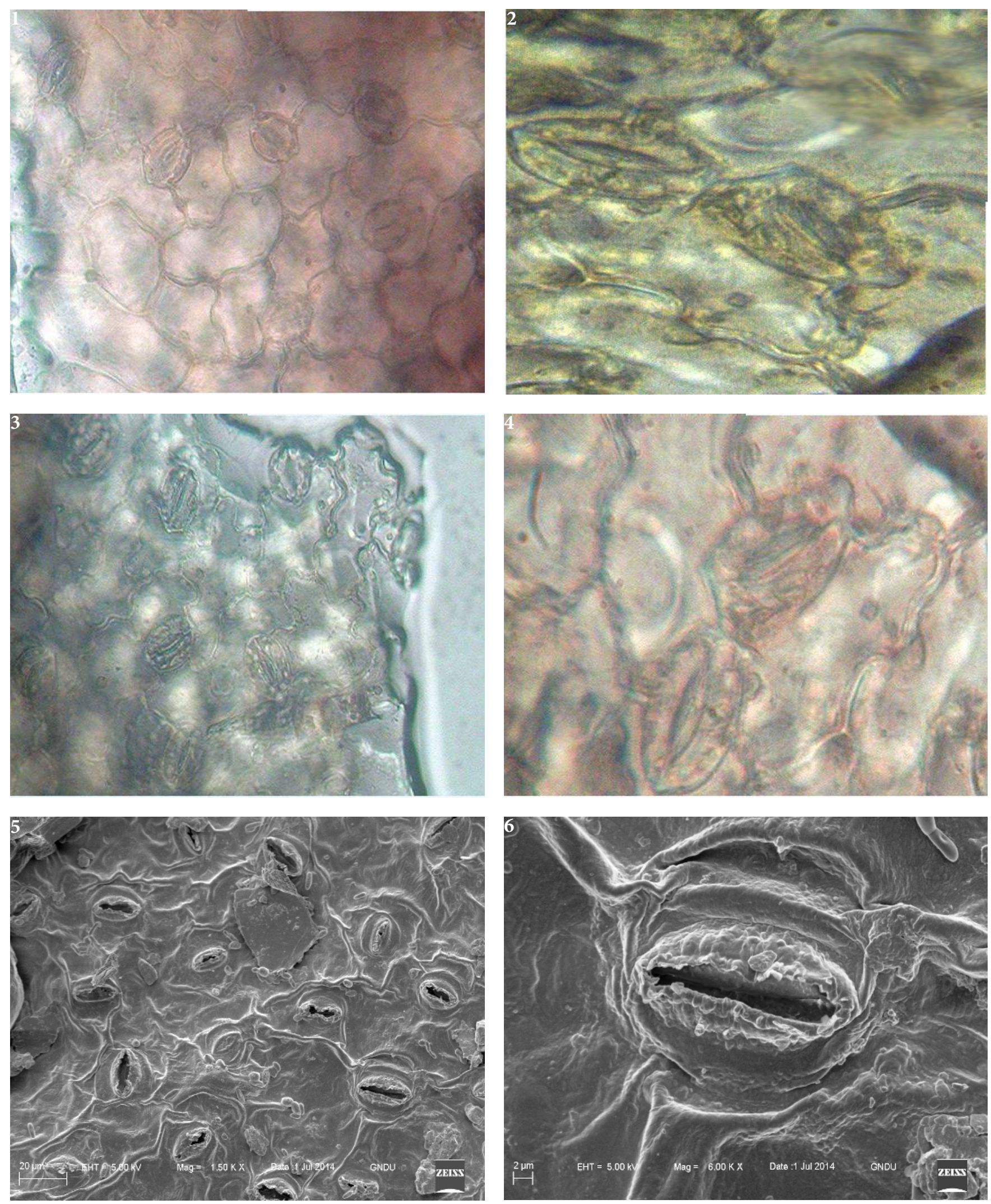

Plate -X. Light (1 - 4) and Scanning Electron Micrographs $(5,6)$ of stomata of Wedelia trilobata (L.) A.S. Hitchc.; 1, 2-abaxial surface (40x, 100x); 3, 4 - adaxial surface (40x, 100x); 5, 6 - abaxial surface (1.50Kx, 6.00Kx, scale bar- $20 \mu \mathrm{m}, 2 \mu \mathrm{m})$. 

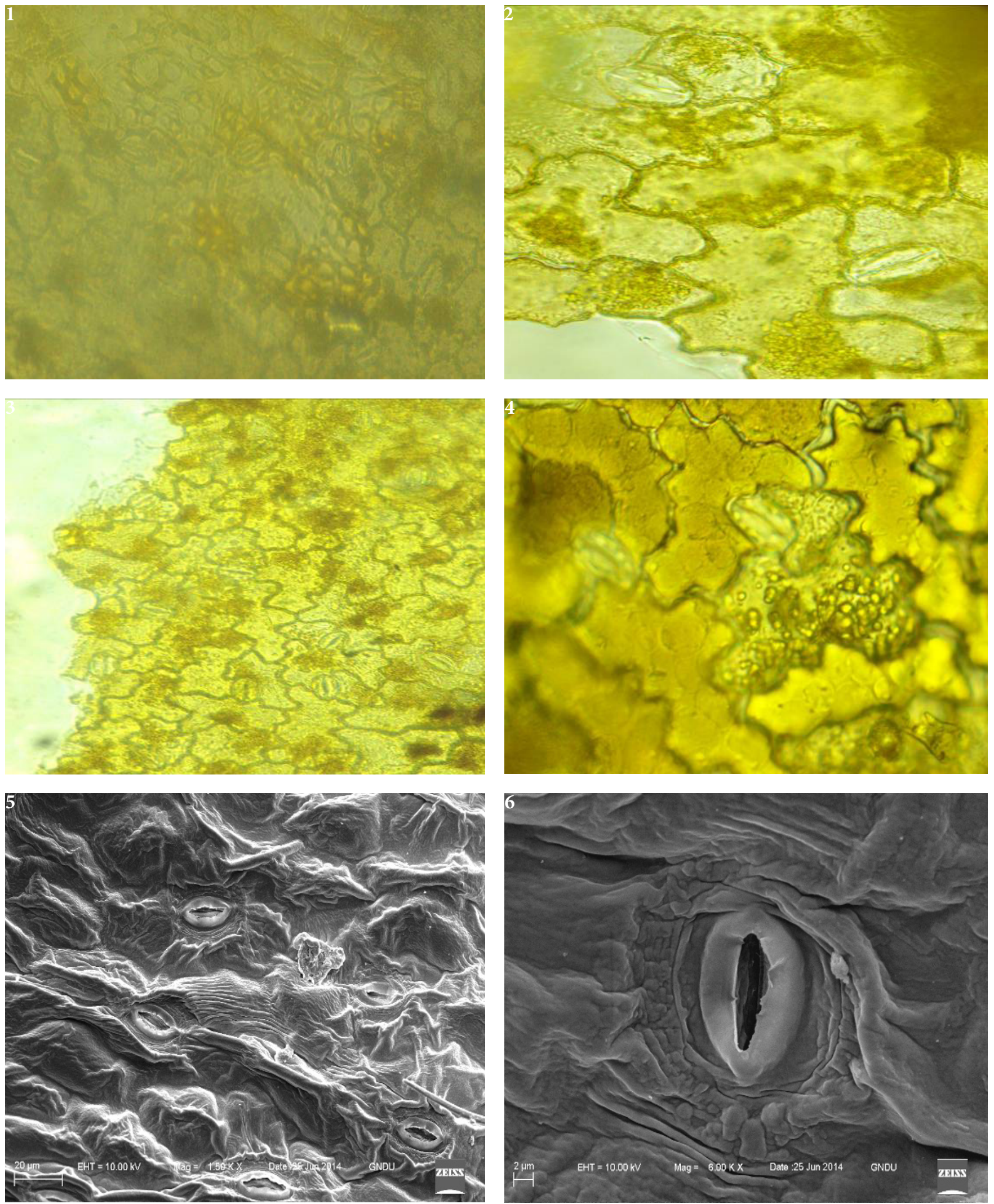

Plate -XI. Light (1 - 4) and Scanning Electron Micrographs (5, 6) of stomata of Zinnia multiflora L.; 1, 2- abaxial surface (40x, 100x); 3, 4 - adaxial surface (40x, 100x); 5, 6 - abaxial surface (1.50 Kx, 6.00kx, scale bar- $20 \mu \mathrm{m}, 2 \mu \mathrm{m})$. 

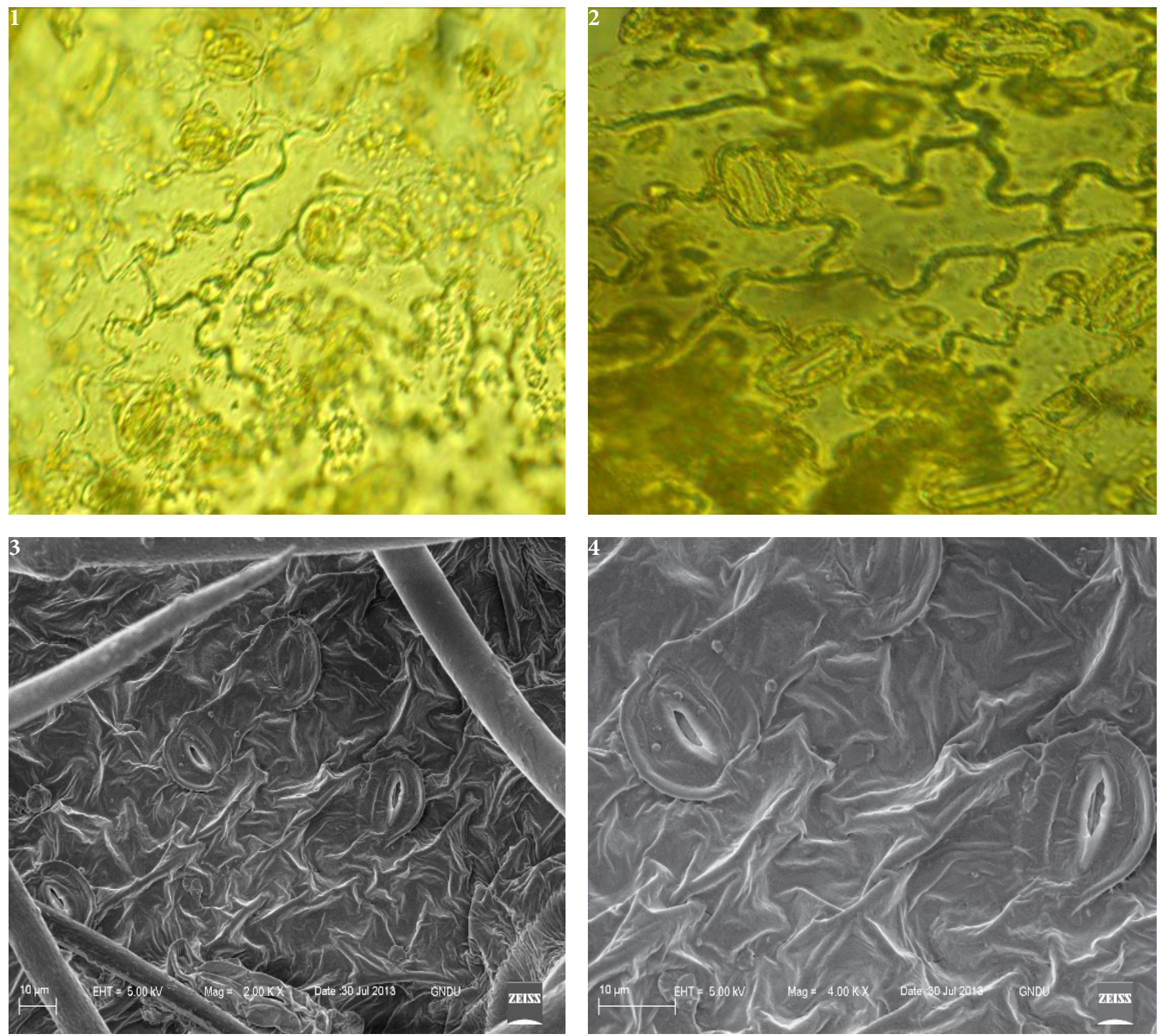

Plate -XII. Light (1 - 2) and Scanning Electron Micrographs $(3,4)$ of stomata of Blumea mollis D. Don.; 1- abaxial surface (40x); 2- adaxial surface (100x); 3, 4 - abaxial surface $(2.00 \mathrm{Kx}, 4.00 \mathrm{Kx}$, scale bar- $10 \mu \mathrm{m}, 10 \mu \mathrm{m})$.

on adaxial surface of leaves. Length of stomatal pore ranged from $8.69 \pm 0.898$ (Verbescinia enceliodes) to $30.08 \pm 0.344$ (Zinnia multiflora) on abaxial surface of the leaves and $10.49 \pm 0.55$ (Verbescinia enceliodes) to $31.19 \pm 0.63$ (Zinnia multiflora) on adaxial surface of the leaves.

Pataky (1969) classified stomata with guard cells on the basis of size as 'small'-meaning less than $15 \mu \mathrm{m}$; medium - between $15 \mu \mathrm{m}$ and $38 \mu \mathrm{m}$; large - meaning more than $38 \mu \mathrm{m}$. As can been seen from Table 3, stomata of 13 species were of medium size and only two species Gillardia pulchella and Zinnia multiflora showed stomata to be of large size. It is generally considered that small stomata gives high stomatal density and that large stomata give low stomatal density (Metcalfe and Chalk, 1988; Beerling and Woodward, 1997). In our study, this statement holds true for Gillardia pulchella but not for Zinnia multiflora where the size of stomata was maximum among all the species studied but stomatal density was not minimum but rather medium. 

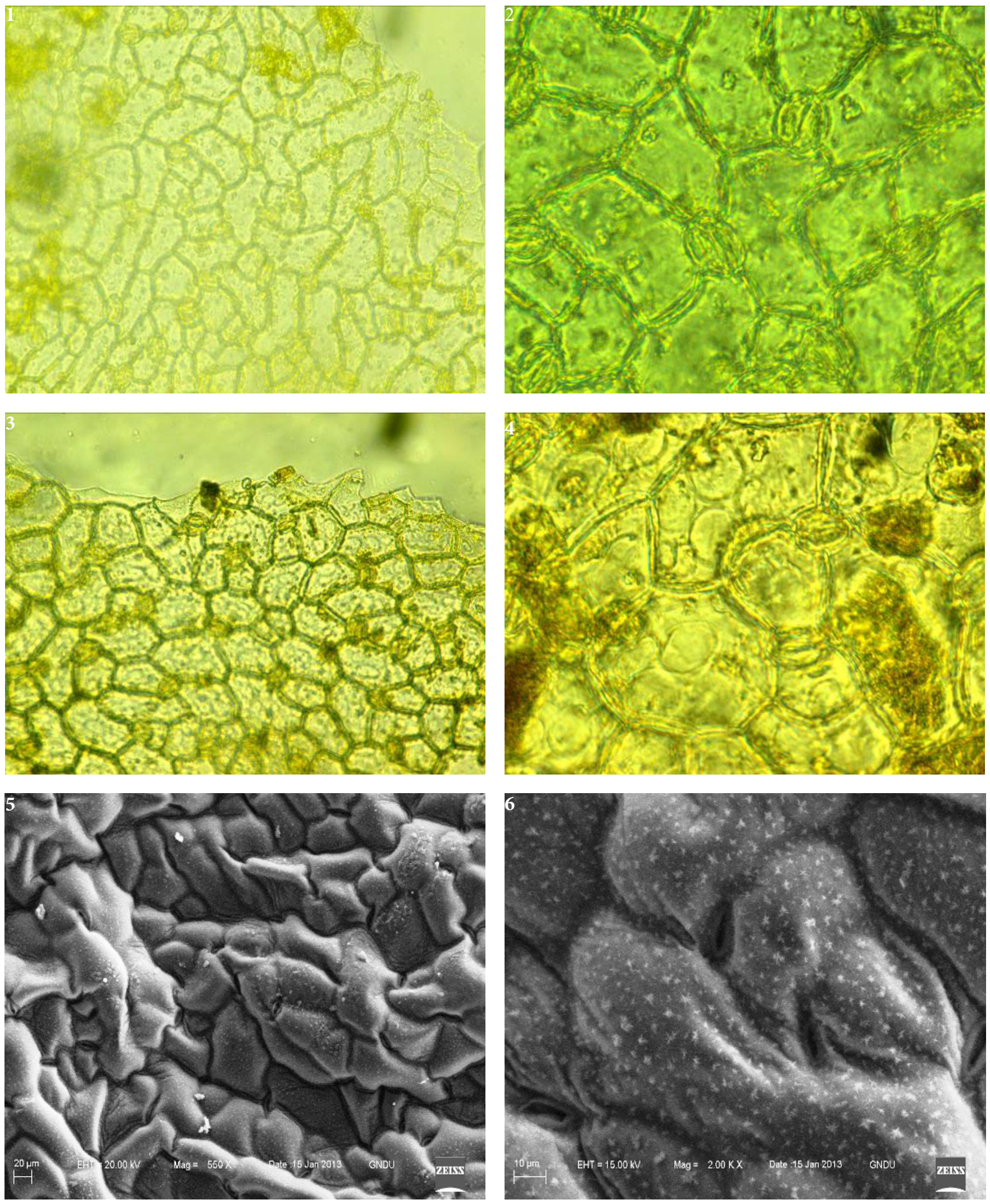

Plate -XIII. Light (1 - 4) and Scanning Electron Micrographs $(5,6)$ of stomata of Launaea residifolia L.; 1, 2- abaxial surface (40x, 100x); 3, 4 - adaxial surface (40x, 100x); 5, 6 - abaxial surface (550x, 2.00Kx, scale bar- $20 \mu \mathrm{m}, 10 \mu \mathrm{m})$. 

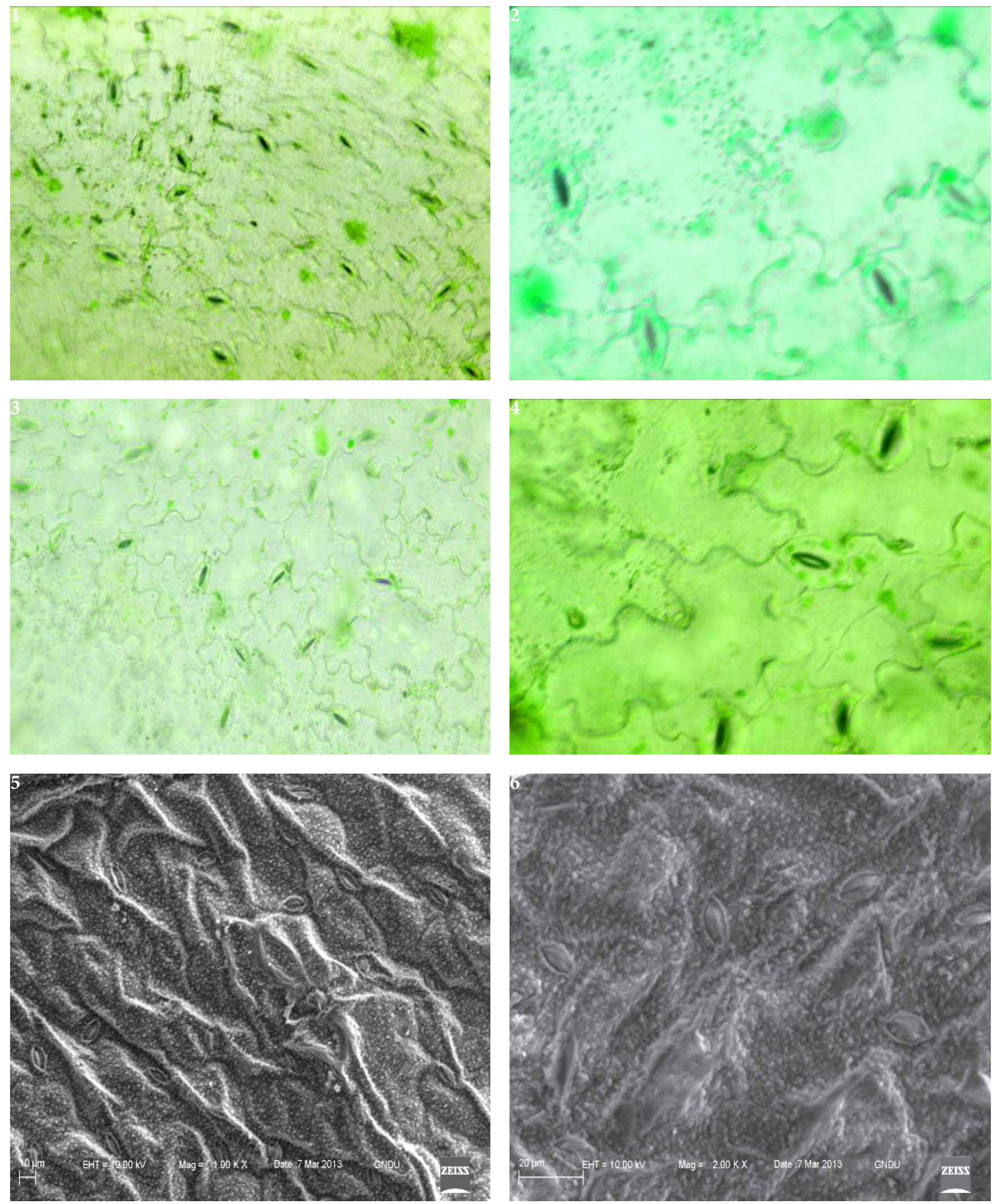

Plate -XIV. Light (1 - 4) and Scanning Electron Micrographs $(5,6)$ of stomata of Sonchus oleraceus L.; 1, 2- abaxial surface (40x, 100x); 3, 4 - adaxial surface (40x, 100x); 5, 6 - abaxial surface $(1.00 \mathrm{Kx}, 2.00 \mathrm{Kx}$, scale bar- $10 \mu \mathrm{m}, 20 \mu \mathrm{m})$. 

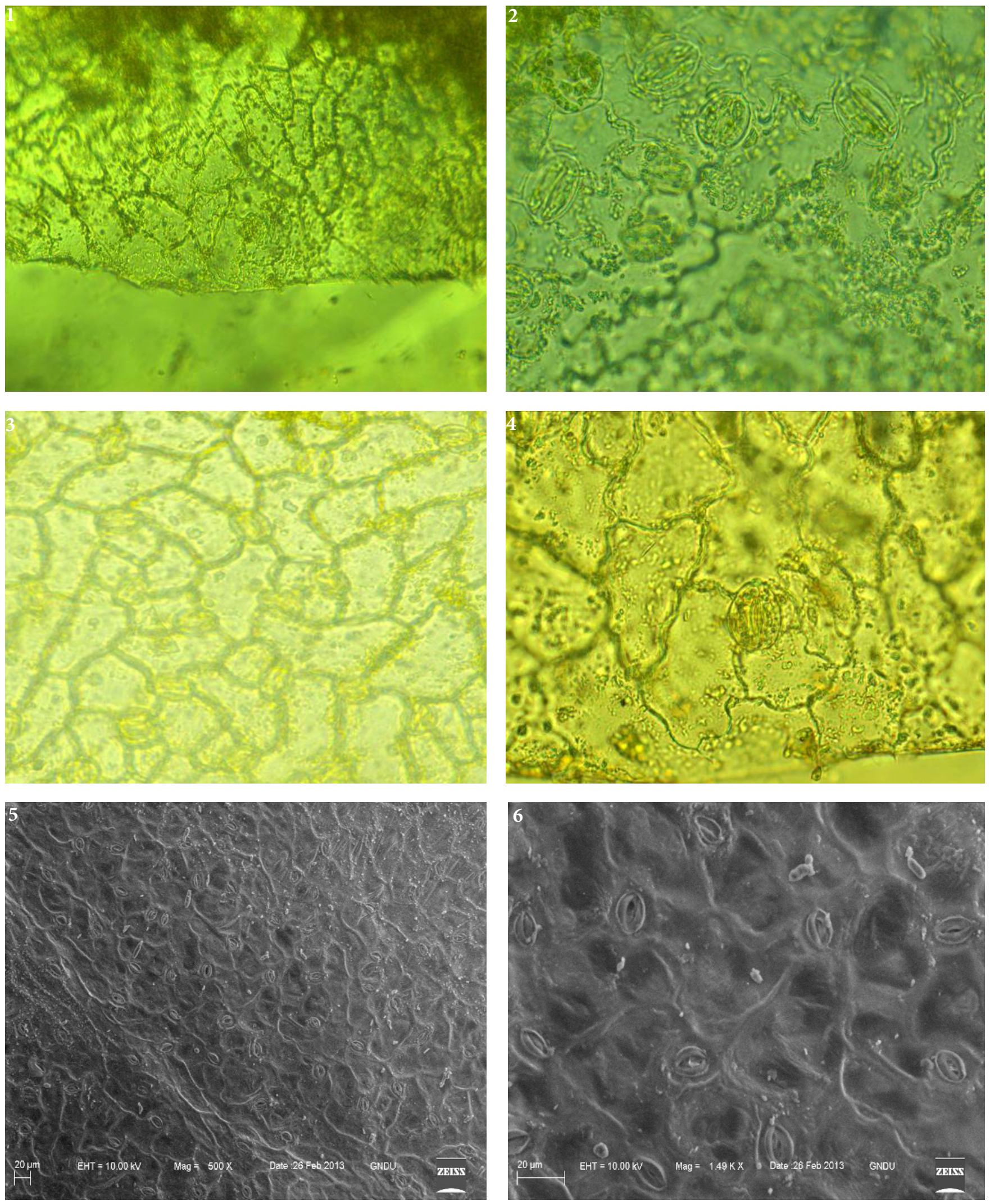

Plate -XV. Light (1 - 4) and Scanning Electron Micrographs $(5,6)$ of stomata of Sonchus wightianus DC.; 1, 2- abaxial surface (40x, 100x); 3, 4 - adaxial surface (40x, 100x); 5, 6 - abaxial surface (500x, $1.49 \mathrm{Kx}$, scale bar- $20 \mu \mathrm{m}, 20 \mu \mathrm{m})$ 
Table 3: Dimensions and state of open/closed stomata of some species of Asteraceae

\begin{tabular}{|c|c|c|c|c|c|c|c|c|}
\hline \multirow[t]{2}{*}{ Tribe } & \multirow[t]{2}{*}{ Sub Tribe } & \multirow[t]{2}{*}{ Plant Name } & \multicolumn{2}{|c|}{$\begin{array}{l}\text { Length of stomata (stomatal } \\
\text { pore }+ \text { guard cells })(\mu \mathrm{m}) \\
(\text { Mean } \pm \text { S.E })\end{array}$} & \multicolumn{2}{|c|}{$\begin{array}{c}\text { Width of stomata ( stomatal } \\
\text { pore + guard cells) }(\mu \mathrm{m}) \\
(\text { Mean } \pm \text { S.E })\end{array}$} & \multicolumn{2}{|c|}{$\begin{array}{c}\text { Length of the stomatal } \\
\text { pore only }(\mu \mathrm{m}) \\
(\text { Mean } \pm \text { S.E })\end{array}$} \\
\hline & & & Abaxial & Adaxial & Abaxial & Adaxial & Abaxial & Adaxial \\
\hline Astereae & & $\begin{array}{l}\text { Erigeron } \\
\text { bonariensis L. }\end{array}$ & $25.12 \pm 0.58$ & $26.98 \pm 0.96$ & $17.66 \pm 0.28$ & $19.73 \pm 0.40$ & $16.42 \pm 0.63$ & $15.59 \pm 0.68$ \\
\hline \multirow[t]{3}{*}{ Cichorieae } & Lactuceae & $\begin{array}{l}\text { Launaea } \\
\text { residifolia L. }\end{array}$ & $25.81 \pm 0.77$ & $21.25 \pm 0.62$ & $19.41 \pm 0.44$ & $16.01 \pm 0.22$ & $16.28 \pm 0.94$ & $12.7 \pm 0.79$ \\
\hline & & $\begin{array}{l}\text { Sonchus } \\
\text { oleraceus L. }\end{array}$ & $23.6 \pm 0.25$ & $25.81 \pm 0.74$ & $20.7 \pm 0$ & $13.11 \pm 0.31$ & $12.56 \pm 0.25$ & $10.76 \pm 0.40$ \\
\hline & & $\begin{array}{l}\text { Sonchus } \\
\text { wightianus DC. }\end{array}$ & $25.53 \pm 0.59$ & $25.94 \pm 0.68$ & $19.87 \pm 0.75$ & $20.29 \pm 0.77$ & $13.87 \pm 0.39$ & $13.25 \pm 0.90$ \\
\hline \multirow[t]{8}{*}{ Heliantheae } & & $\begin{array}{l}\text { Cosmos } \\
\text { bipinnatus Cav. }\end{array}$ & $28.29 \pm 0.72$ & $24.29 \pm 0.85$ & $18.35 \pm 0.41$ & $16.01 \pm 0.62$ & $15.87 \pm 0.78$ & $13.8 \pm 0.65$ \\
\hline & & $\begin{array}{l}\text { Eclipta alba (L.) } \\
\text { Hassk. }\end{array}$ & $17.94 \pm 0.36$ & $23.74 \pm 0.54$ & $15.33 \pm 0.25$ & $14.77 \pm 0.34$ & $12.42 \pm 0.36$ & $13.52 \pm 0.45$ \\
\hline & & $\begin{array}{l}\text { Gillardia } \\
\text { pulchella L. }\end{array}$ & $48.99 \pm 0.93$ & $48.16 \pm 5.37$ & $32.84 \pm 0.54$ & $35.88 \pm 0.72$ & $28.29 \pm 0.31$ & $30.91 \pm 0.23$ \\
\hline & & $\begin{array}{l}\text { Helianthus } \\
\text { annuus L. }\end{array}$ & $31.6 \pm 0.78$ & $29.95 \pm 0.68$ & $21.11 \pm 0.65$ & $20.01 \pm 0.23$ & $19.87 \pm 0.69$ & $19.6 \pm 0.28$ \\
\hline & & $\begin{array}{l}\text { Parthenium } \\
\text { hysterophorus L. }\end{array}$ & $21.94 \pm 0.14$ & $22.08 \pm 2.1$ & $16.56 \pm 0.00$ & $16.84 \pm 0.19$ & $10.76 \pm 0.28$ & $11.04 \pm 0.36$ \\
\hline & & $\begin{array}{l}\text { Verbescinia } \\
\text { enceliodes (Cav.) } \\
\text { Bentham \& } \\
\text { Hooker fil. ex } \\
\text { Gray }\end{array}$ & $21.8 \pm 1.35$ & $23.18 \pm 1.69$ & $19.6 \pm 1.16$ & $19.18 \pm 1.04$ & $8.694 \pm 0.89$ & $10.49 \pm 0.55$ \\
\hline & & $\begin{array}{l}\text { Wedelia trilobata } \\
\text { (L.) A.S. Hitchc. }\end{array}$ & $26.22 \pm 0.65$ & $28.15 \pm 0.75$ & $22.77 \pm 0.93$ & $22.77 \pm 0.42$ & $16.56 \pm 0.41$ & $16.56 \pm 0.29$ \\
\hline & & $\begin{array}{l}\text { Zinnia } \\
\text { multiflora L. }\end{array}$ & $52.72 \pm 0.54$ & $53.54 \pm 0.68$ & $31.46 \pm 0.35$ & $36.86 \pm 1.18$ & $30.08 \pm 0.34$ & $31.19 \pm 0.62$ \\
\hline \multirow[t]{2}{*}{ Inuleae } & Gnaphaleae & $\begin{array}{l}\text { Gnaphalium } \\
\text { purpureum L. }\end{array}$ & $23.46 \pm 0$ & $22.08 \pm 0.58$ & $20.7 \pm 0$ & $16.56 \pm 0$ & $13.8 \pm 5 \mathrm{E}-08$ & $12.7 \pm 0.54$ \\
\hline & Plucheineae & $\begin{array}{l}\text { Blumea mollis D. } \\
\text { Don. }\end{array}$ & $22.36 \pm 0.34$ & $24.01 \pm 0.47$ & $19.32 \pm 0.29$ & $21.25 \pm 1.15$ & $13.52 \pm 0.34$ & $14.35 \pm 0.47$ \\
\hline Tageteae & & Tagetes erecta $\mathrm{L}$. & $23.32 \pm 0.86$ & $20.84 \pm 0.32$ & $14.21 \pm 0.21$ & $14.35 \pm 0.23$ & $15.18 \pm 0.58$ & $13.52 \pm 0.28$ \\
\hline
\end{tabular}

S. E- Standard Error 


\section{ACKNOWLEDGEMENTS}

The authors thank University Grant Commission, New Delhi for CPEPA, UPE and DRS programs for financial assistance and Department of Science and Technology, Government of India, New Delhi for INSPIRE Fellowship to Mrs. Harpreet Kaur and FIST and PURSE programs. We also acknowledge Prof. Anish Dua, In charge SEM facility, Guru Nanak Dev University, Amritsar and Mr. Kanwaljit Kumar for help in SEM analysis.

\section{REFERENCES}

ADEDEJI, O. AND H. C. ILLOH 2004. Comparative foliar anatomy of 10 species in the genus Hibiscus Linn. In Nigeria. New Bot 31: 147-180.

ADEDEJI, O. 2004. Leaf epidermal studies of the species of Emilia Cass (senecioneae, Asteraceae) in Nigeria. Bot. Lith. 10(2): 121-133.

BEERLING, D. J. AND F. I. WOODWARD 1997. Changes in land plant function over the Phanerozoic: reconstructions based on the fossil record. Bot. J. Linn. Soc. 124: 137-153.

BREMER, K. 1994. Asteraceae: Cladistics and Classification. Timber Press, Portland, Oregon.

CELKA, Z. P. SKUDLARZ AND U. BIEREZNOJ 2006. Morphological variation of hairs in Malva alcea L. (Malvaceae). Biodivers. Res. Conserv. 3: 258-261.

DEHGAN, B. 1980. Application of epidermal morphology to taxonomic delimitations in the genus Jatropha L. Euphorbiaceae. Bot. J. Linn. Soc. 80: 257-278.

DILCHER, D. L. 1974. Approaches to the identification of angiosperm leaf remains. Bot. Rev. 40 (1): 1-157.

DUTTA, A. C. 1974. Botany for Degree Students. Calcutta, Oxford University Press. Delhi Bombay Madras.

FUNK, V. A., R. J. BAYER, S. KEELE, R. CHAN, L. WATSON, B. GEMEIN-HOLZER, E. SCHILLING, J. L. PANERO, B. G. BALDWIN, GARCIA- JA, N. CAS, A. SUSANNA AND R. K. JANSEN 2005. Everywhere but Antarctica: using a supertree to understand the diversity and distribution of the Compositae. Biol. Skr. 55: 343-374.

HILU, K. W. AND J. L. RANDALL 1984. Convenient method for studying grass leaf epidermis. Taxon 33(3): 413-415.

JAYEOLA, A. A. AND J. R. JADENEGAN 2001. Macro morphological studies of the West Africa Rhizophora L. Feddes Repert. 112: 349-356.

MAHBUBUR RAHMAN, A. H. M., A. K. M RAFIUL ISLAM AND M. MATIUR RAHMAN 2013. An anatomical investigation on Asteraceae family at Rajshahi Division, Bangladesh. Int. J. Biosci 3(1): 13-23.

MBAGWU, F. N., AND H. O. EDEOGA 2006. Palynological studies on some Nigerian species of Vigna Savi. J. Biol. Sci 6: $1122-1125$.

METCALFE, C. R., AND L. CHALK 1950. Anatomy of the Dicotyledons. Vol. 1. Claredon Press, Oxford, U.K. pp. 40-116.

METCALFE, C. R., AND L. CHALK. 1988. Anatomy of the Dicotyledons. Vol. 1. 2nd Edition. 100-106. Clarendon Press, Oxford.

MUNIR, M, M. A. KHAN, M. AHMED, A. BANO, S. N. AHMED, K. TARIQ, S. TABASSUM, T. MUKHTAR, M. AMBREEN AND S. BASHIR 2011. Foliar epidermal anatomy of some ethnobotanically important species of wild edible fruits of northern Pakistan. J. Med. Plants Res. 5(24): 5873-5880.

NOGGLE, G. R., AND G. J. FRIT. 1976. Introductory Plant Physiology. Prentice-Hall Inc., USA. pp. 322

OKEKE, S. E. 2004. The taxonomic position of members of the so-called Dioscorea cayenensis - rotundata complex (Dioscoreaceae). Niger. J. Bot 17, 95-103.

PARVEEN, N. S., K. S. R. MURTHY AND T. PULLAIAH 2000. Leaf epidermal characters in Crotalaria species (Papilionoidea) from Eastern Ghats. Phytomorphology 50: 205-212.

PATAKY, S. 1969. Leaf epidermis of Salix, In: Metcalfe, C. R. \& L. Chalk (Eds). Anatomy of the Dicotyledons, Vol. 1, 2nd Edition, p. 100. Clarendon Press, Oxford.

PERVEEN, A., R. ABID AND R. FATIMA 2007. Stomatal types of some dicots within flora of Karachi, Pakistan. Pak. J. Bot 39(4): 1017-1023.

RAHMAN, A. H. M. M., A. K. M. R. ISLAM, M. M. RAHMAN 2011. The Family Asteraceae of Rajshahi Division, Bangladesh. VDM Verlag Dr. Muller Publishing House Ltd. Germany.

RAHMAN, A. H. M. M. 2013. Systematic studies on Asteraceae in the northern region of Bangladesh. Am. J. Lif. Sci. 1(4): $155-164$.

SHAHEEN, S, M. AHMAD, N. HAROON, F. KHAN, R. A. HUSSAIN, M. ZAFAR, S. RAMZAN, R. AYUB AND Z. KHALID 2012. Systematic and ethnopharmacognostic investigation of selected medicinal plants of family Asteraceae. Afr. J. Pharm. Pharmacol. 6(46): 3184-3194.

YASMIN, G. M., A. KHAN, N. SHAHEEN AND M. Q. HAYAT 2009. Micromorphological investigation of foliar anatomy of genera Aconogonon and Bistorta of family Polygonaceae. Int. J. Agric. Biol. 11: 285-289.

ZOU, P, J. LIAO AND D. ZHANG 2008. Leaf epidermal micromorphology of Cercis (Fabaceae: Caesalpinioideae). Bot. J. Linn, Soc. 158: 539-547. 